\title{
Armillaria Pathogenesis under Climate Changes
}

\author{
Katarzyna Kubiak ${ }^{1, *}$, Anna Żółciak ${ }^{1}$, Marta Damszel ${ }^{2}$, Paweł Lech ${ }^{1}$ and Zbigniew Sierota ${ }^{3}$ \\ 1 The Forest Research Institute, Department of Forest Protection, Sękocin Stary, ul. Braci Leśnej 3, \\ 05-090 Raszyn, Poland; a.zolciak@ibles.waw.pl (A.Ż.); p.lech@ibles.waw.pl (P.L.) \\ 2 Department of Entomology, Phytopathology and Molecular Diagnostics, University of Warmia and Mazury \\ in Olsztyn, Prawocheńskiego 17, 10-721 Olsztyn, Poland; marta.damszel@uwm.edu.pl \\ 3 Department of Forestry and Forests Ecology, University of Warmia and Mazury in Olsztyn, Plac Łódzki 2, \\ 10-727 Olsztyn, Poland; zbigniew.sierota@uwm.edu.pl \\ * Correspondence: k.kubiak@ibles.waw.pl; Tel.: +48-22-715-0-635
}

Academic Editors: Matteo Garbelotto, Paolo Gonthier and Timothy A. Martin

Received: 21 January 2017; Accepted: 23 March 2017; Published: 27 March 2017

\begin{abstract}
Climate changes influencing forest ecosystems include increased air temperatures and $\mathrm{CO}_{2}$ concentrations as well as droughts and decreased water availability. These changes in turn effect changes in species composition of both host plants and pathogens. In the case of Armillaria, climate changes cause an increase in the activity of individual species and modify the growth of rhizomorphs, increasing the susceptibility of trees. The relationship between climate changes and the biotic elements of Armillaria disease are discussed in overview.
\end{abstract}

Keywords: Armillaria; rhizomorphs; climate changes

\section{Introduction}

The total $\mathrm{CO}_{2}$ amount together with other greenhouse gases in the atmosphere has led to increasing global temperatures [1,2]. Many authors have suggested that concentrations of $\mathrm{CO}_{2}$ will increase to as much as $550 \mathrm{ppm}$ by 2050 and $1250 \mathrm{ppm}$ by the end of the twenty-first century [3-5]. Pearson and Dawson [6] reviewed models of climate change impacts on biodiversity and on the distribution of vegetation, and they point out the role of other important factors such as "biotic interactions, evolutionary change and dispersal ability." Global warming will change the special diversity and functional activity of forests-affecting, for example, factors such as photosynthetic rate, tree dieback and wood production, as well as the activity of pests and pathogens-in Central Europe [3,7]. Wargo [8,9] found that defoliation of trees can substantially decrease the starch content in the root wood and the sucrose levels in both bark and cambial tissues of sugar maple roots, which should decrease the attractiveness of these tissues for root pathogens. However, defoliation may also reduce the nutrition available to mycorrhizae and reduce their ability to contribute to water and nutrient uptake for the tree [10].

Taking into consideration that conifers will probably suffer the impacts of global warming in South and Central Europe, including shifting climate zones, one can logically expect changes in the geographic distribution of boreal species. This may include an expansion of deciduous species in the north-east direction, and a decrease in conifer abundance, mainly Norway spruce [11]. "Increased temperatures and subsequent drying due to climate change will increase the presence of "new" hosts on "new" sites." These biotic shifts may favor the initiation of new disease phenomena and increases in invasive species (e.g., those on the European and Mediterranean Plant Protection Organization Alert List), affecting the life of the "new" forest ecosystems [12]. As the coniferous habitats retreat, however, the potential increase in the range of deciduous forests (especially oak, beech, and alder) is unlikely to be fully realized, if only because of the trees dying due to active phytophthorosis and simultaneous Armillaria rot in these species. 
Atmospheric $\mathrm{CO}_{2}$ concentrations, warming, and altered precipitation regimes can limit both ecosystem productivity and activity, and change community composition and function [13-15], favoring organisms better adapted to higher temperatures and faster growth rates [16-18]. However, unfavorable relationships between fungi and $\mathrm{CO}_{2}$ in the forests have also been detected. With the damage to 80 - to 100 -year-old Scots pine stands by root pathogens reaching $20 \%$ of the trees per ha, and up to $80 \%$ for Norway spruce, the degradation of roots and stumps could amount to $15.3 \mathrm{~m}^{3} /$ ha of pine and $100.7 \mathrm{~m}^{3} /$ ha of spruce [19]. Assuming that the proportion of the cellulose and lignin together average $70 \%$ of wood pulp, one can easily calculate how much $\mathrm{CO}_{2}$ is released as a result of fungal enzymatic degradation. Sierota [19] estimates that from one hecture of 80-year-old pine stand, 60 tons of $\mathrm{CO}_{2}$ is released in this way per year, or $3.3 \mathrm{Mt}$ for all Polish forests. However, root pathogens are not the only organisms decaying wood in the forest-one should also take into account saprotrophs colonizing the so-called "dead wood".

Climate change will increase the frequency of extreme climatic conditions, such as droughts, floods, and hurricanes. Forest damage by wind and snow are projected to increase. Some insect species will profit from increasing temperatures, especially at their northern limits. The risk of outbreaks will probably be increased by milder winters that ease the survival of insect and pathogen species during hibernation [20]. In such conditions, there is a high probability that forests will be subject to increased frequency and intensity of fungal diseases. The effects may become more disastrous because of drought and flooding, which are known as factors that predispose trees to several pathogens [21]. Changes in temperature and humidity affect pathogen sporulation and dispersal, and so changes in climatic conditions may favor certain pathogens [22]. Sudden weather changes may increase the incidence of dispersal of pathogens, thereby changing the geographic extent of diseases. Pathogens can meet new hosts and new vectors which may lead to the emergence of new risks due to changes in the species composition of trees or because of invasive species [21].

A. mellea (Vahl. Fr) Kummer and A. ostoyae (Romagnesi) Herink are already known to be strong pathogens present in Europe, but they will further benefit from a situation where trees become more stressed due to climatic effects [23] or risks posed to storm-damaged stands [21,24]. Armillaria spp. grow at temperatures between 10 and $31^{\circ} \mathrm{C}$, with an optimum between 20 and $22{ }^{\circ} \mathrm{C}[25,26]$. According to Rind and Losel, the mycelial growth of A. mellea and A. gallica appears to be greater at higher temperatures $[21,27]$. This may mean that in a warming climate, low soil temperatures probably will not restrict the growth of rhizomorphs during winter as it usually happens in most northern temperate zones [21]. A. gallica will probably prefer to attack trees weakened more by changing climatic factors, both because this species of fungus is quite thermophilic (A. Mellea), and because it acts like a weak parasite that attacks and sometimes kills weakened trees. Armillaria gallica is a likely candidate for an opportunistic pathogen that may become problematic due to climate change, due to increased stress of "host" trees caused by increased temperatures and drought [21,28].

The global rising temperature of the atmosphere and the soils can accelerate the mycelial growth of root pathogens and therefore increase wood decay and $\mathrm{CO}_{2}$ release. Pastor and Post [29] indicated an important role for temperature, water availability, and nitrogen uptake in the vitality of forest ecosystems. Schwarze et al. [30] found that the temperature range for mycelial growth and wood decay is $5-30{ }^{\circ} \mathrm{C}$, although many fungi can grow at higher temperatures, even $+55^{\circ} \mathrm{C}$. However, Witomski [31] found that the optimal temperature range for wood decay is $18-27^{\circ} \mathrm{C}$ and below or above this range the decay of wood tissues is decreased.

Pathogens and saprotrophs decomposing timber (mostly polypore basidiomycetes) showed better growth with higher temperatures of growth medium. These fungi benefited from the water formed during enzymatic decomposition, as the humidity of the substrate increases with the degree of decomposition of the timber tissue [32,33]. The development of hyphae of wood decay fungi also occurs in winter, when it is supported by high osmotic pressure and thermal energy emitted during the decomposition of cellulose and lignin. The low concentration of $\mathrm{CO}_{2}$ in the rhizosphere, on the root surface and inside the wood, has a significant beneficial effect on the development of 
the spores and mycelia of many different fungi promoting their colonization of the dead wood on the forest floor [34-37]. Wells and Boddy [37] found that increased temperatures had a positive effect on soil phosphorus uptake by the mycelia of some basidiomycetes. Because temperature is the main factor affecting organic matter decomposition, taxa that regulate decomposition, such as fungi and macro-arthropods, may shift their activity or community composition in response to warming [38,39]. According to Austin [38], wood decomposition increases with temperature, but the impact of temperature might vary at sites with different climatic regimes and decomposer communities. The author predicted that warming would have larger impacts on fungal community composition at sites already under heat stress [38].

The direct and indirect impacts of climatic changes affect the health of forests in part by influencing the development of fungal diseases and insect pests [40-42]. Increases in root diseases, particularly those caused by Armillaria pathogens [41-43], contribute notably to these impacts. Diseases caused by this fungus can increase under drought conditions and temperature increases [41], which can lead to the reduced tree growth and attacks by secondary pests [44]. Ayres and Lombardero [45] indicated that climate change affects fungal diseases by (i) direct impact on the growth of hosts and pathogens; (ii) changes in tree defense mechanisms; and/or (iii) an indirect effect on the mutualist and competitive organisms and others in the environment, manifesting in changes in abundance and frequency. Klopfenstein et al. [40] proposed a mathematical model to predict the impact of climate change on the pathogen A. ostoyae attacking Douglas fir in the northwestern USA. He emphasized that the integration of a variety of tools and data is necessary to improve forecasts for the influence of climate on forest diseases.

The multifunctional interactions between plants and soil communities influenced the selective pressures of pathogens, including Armillaria spp., on the functional features of the plants [46,47]. Because the responses of soil microorganisms to Armillaria pathogenesis are not well-known, it is still of great importance to investigate how the climatic parameters could influence not only the Armillaria pathosystem and host-tree susceptibility, but also soil community composition and microbial activity.

\section{The Pathogen}

For many decades, root and butt rot caused by Armillaria mellea (sensu lato) has been a significant threat to the boreal forests of Europe and North America. Currently, it seems to have become the most important phytopathological problem in weakened managed forests [48]. Expansion of the pathogen in colonized tissues is rather fast, depending on the tree species and health status of the host as well as on the vigor of the mycelium (which in turn is affected by the species and clone of Armillaria acting as the pathogen) $[49,50]$. The pathogenesis of Armillaria is described in many papers and books; however, the role of the environment in this process is rather neglected [51,52]. The intensity of losses caused by the pathogen is directly connected with changes in the climate and with weather anomalies. Long and frequent drought periods, increases in global and local $\mathrm{CO}_{2}$, summer reduction of soil moisture, and escape of available water are all relatively strong factors [53]. The deep impact of soil drought on Armillaria rot disease has been described by previous authors [40,54-57]. Źółciak et al. [58] found that after drought in Poland in 2000, the disease was noted in an area of 150 thousand hectares in Norway spruce stands as late as 2005. The interactions between air and soil $\mathrm{CO}_{2}$ and Armillaria behavior have been the subject of current and past investigations [19,36,53].

The life cycle of Armillaria spp. is very complicated, and is characterized by: different gametogenesis cycles (mono-, di-, eu-karyotic), different phases in ecological status (pathogenic, saprotrophic, orchid-like symbiotic), different methods of infection (basidiospores, mycelium, rhizomorphs), and different host reactions (tissue compartmentalization, resin outflow, host dying, wood decay) [59]. This sophisticated behavior can be additionally modified by site conditions, weather anomalies, and human activity, as it was described in Canadian boreal forests [60]. While Armillaria ostoyae favors fertile mountain forests and either pure Norway spruce or mixed spruce-beech stands in Poland [36], other Armillaria species can inhabit various forest stands in many 
sites [61]. There is lack of publications about different species of Armillaria in different habitats within the context of climate changes.

The pathogenicity of the known Armillaria species depends on the individual virulence, host species, age of the tree, and influence of the environment [62-66]. In Europe, Sicoli et al. [67] found that A. mellea (Vahl: Fr.) P. Kummer and A. gallica Marxmüller \& Romagnesi were the most pathogenic species for some Quercus spp. seedlings, whereas other authors showed A. ostoyae (Romagnesi) Herink as being the most dangerous for conifer species [21,63]. Armillaria borealis Marxmüller \& Korhonen, A. cepistipes Velenovsky, and A. gallica are generally described as weakly pathogenic species or pathogens of weak trees [28,68], while A. tabescens (Scop.: Fr.) Emel. is regarded as a typical saprotroph. Nevertheless, some of the opportunistic parasite species such as A. ectypa can infect some stressed trees [69]. Armillaria ectypa (Fr.) Lamoure plays a rather minor role as a disease perpetrator [70]. The number of Armillaria species worldwide is still uncertain; recently some isolated species were identified as A. nigritula Orton or renamed A. altimontana Brazee, B. Ortiz, Banik \& D.L. Lindner (previously described as NABS X) [71-73].

Armillaria rhizomorphs are described as the main source of threat to roots in the pathogenesis of infection. They may also be considered to be an example of a special morphological adaptation of this fungus to different environmental conditions [74,75].

\section{The Rhizomorphs}

Armillaria commonly occur as rootlike rhizomorphs growing on plant debris or epiphytically attached to the root system of dead, diseased, or healthy host plants [74-79]. Rhizomorphs look like roots or cords that are a dark brown color when old and a reddish brown color when young. Hence, sometimes rhizomorphs have been referred to as mature (black) and immature (red or brown) $[80,81]$ or as maternal (old) and regenerated (young) because of their regenerative abilities [82]. Rhizomorphs grow towards the soil surface, possibly due to the oxygen gradient in soil [83]; however, the seasonal humidity in this layer is what probably adjusts its vertical distribution (e.g., black rhizomorphs were mostly found deeper in dry sites) [25,83]. Rykowski [82] described black rhizomorphs in the soil of rich deciduous stands as persistent organs without infection ability, whereas young, red rhizomorphs were formed mostly in plantations, infecting pines after the removal of stands.

Different species of Armillaria produce rhizomorphs with either a monopodial or dichotomous branching pattern [84-86]. Rhizomorphs typically grow in the soil, but they can also occur on dead trees, stumps, and even on the surfaces of living roots. Where the hosts have physical defects, Armillaria form apical meristems which can produce a large number of new rhizomorphs [82,87-89]. Rhizomorphs and their growing-tip hyphae are a main source of inoculum, initiating the infection processes and host reactions [82,90].

In the initiation and development of rhizomorphs, environmental factors such as moisture, soil temperature, $\mathrm{pH}$, nutrients, and pollution play an important role [25,51,91-93]. These factors determine the proper functioning of apical meristems and the rhizomorphs' growth [78,82]. Redfern [81] and Kessler and Möser [94] found that low soil moisture and temperature inhibit this growth and branching. A temperature higher than $22^{\circ} \mathrm{C}$ is preferred [95]; however, $30^{\circ} \mathrm{C}$ limited the growth of the fungus due to enzyme inactivation [96]. Rhizomorphs can grow in different types of forest and farmland soils. Sandy soils, on the other hand, inhibit their production not only because of low nutrients but also due to a high day-night temperature amplitude $[25,50,97]$. Peat soils are conducive to the development of rhizomorphs, which tend to be concentrated mostly in the humus layer of the soil due to the oxygen concentration gradient. This may be related to increased susceptibility to infections around the root collars of trees $[90,97,98]$. In addition, Armillaria habitats have moist layers of substrate and low levels of oxygen and organic matter, the latter of which is digested by the soil acidic reaction products of decomposers [99]. Mallett and Meynard [100] indicated an increase in the severity of fungus root rot when increasing the content of sand in the mineral substrate layer and decreasing the content of $\mathrm{NH}^{4+}$ 
in the organic layer of the soil, and Singh [95] found that plants in good condition produce a callus, which initiates an effective barrier against Armillaria infection [95].

Lech and Żótciak [101] observed stimulation of $A$. ostoyae rhizomorph production by elevated air $\mathrm{CO}_{2}$ concentration in a chamber experiment. Hintikka [34] noted the stimulation of rhizomorph growth on a medium under high $\mathrm{CO}_{2}$ concentrations. Schinner and Concin [102] showed the ability of some wood rotting fungi, including Armillaria spp., to assimilate $\mathrm{CO}_{2}$ from the air. The rate of this assimilation was low, however, reaching only $1.3 \mathrm{nCi} / \mathrm{g}$ of dry mass in the case of Armillaria spp, which means that $1 \mathrm{~g}$ of fungus tissue contained just $0.017 \mathrm{mg}$ of carbon coming from atmospheric $\mathrm{CO}_{2}$. Unfortunately, studies devoted primarily to the relationship between forest tree species (hosts) and Armillaria spp. (pathogens) in a $\mathrm{CO}_{2}$-enriched atmosphere and/or under increased temperatures are lacking, which makes it extremely difficult to predict the future behavior and functioning of this fungal genus in forest ecosystems under climate change.

\section{The Hosts}

There is yet another aspect of climate change effects on trees. According to the growth-differentiation balance hypothesis (GDBH) [103], the elevation of air $\mathrm{CO}_{2}$ may cause a decrease in trees susceptibility towards herbivores as the augmented availability of carbon resources due to intensified photosynthesis is allocated to secondary metabolites rather than to growth. It was found that plants grown in high air $\mathrm{CO}_{2}$ concentrations were characterized by a higher $\mathrm{C}: \mathrm{N}$ ratio, and increased lignification and phenolic compound content in the tissues compared to plants from ambient air $\mathrm{CO}_{2}$ conditions [104,105]. However, Fleischman et al. [106] found atmospheric $\mathrm{CO}_{2}$ elevation up to ca. 700-800 ppm to cause an increase in beech seedlings' susceptibility to infection by root pathogen Phytophthora citricola. Similarly, Tkaczyk et al. [107] reported a decrease of fine root biomass of beech seedlings grown under $800 \mathrm{ppm}$ air $\mathrm{CO}_{2}$ and exposed to Phytophthora plurivora and Ph. cactorum artificial inoculation. Oszako et al. [108] had similar results with oak seedlings and Ph. quercina.

Pollutants may affect the severity of Armillaria root disease on host plants. Impacts associated with $\mathrm{SO}_{2}$ and other pollutants have been described in the past by many authors [109-113]. Domański [113] found that Armillaria root disease was extremely rare in polluted zones but was quite common in plots uninjured by pollution, while Horak and Tesche [114] described an increased mortality of trees both infected by A. ostoyae and fumigated with $\mathrm{SO}_{2}$. According to Wargo et al. [115], lead and other heavy metals present in the soils of spruce-fir sites at high elevations inhibit both mycelial and rhizomorph growth in culture.

Human land-use practices can also influence the host-parasite relationship. Sicoli et al. [116] reported that $A$. mellea attacks on Cedrus atlantica were predisposed by the specific soil previously used for pasture causing an iron deficiency (as indicated by reduced growth and chlorotic leaves). Silvicultural treatments such as thinning may result in the spread of $A$. ostoyae via root contacts, mainly in juvenile stands [117]. It should be remembered that the Armillaria-decayed roots and rhizomorphs remain as inoculum in the soil for many years. The impact of Armillaria inoculum from coniferous stands on the roots of entering deciduous trees (for example, in reconstruction after conifer monocultures) is not fully understood [118]. On the other hand, the higher temperatures and humidity of soil in cleared sites can indirectly protect roots by the mycoparasitism phenomenon, as occurs in the parasitism of $A$. gallica by mycelia of Trichoderma species [119]. Note, however, that the reverse relationship can occur: Oomycetes seem to be indicated as the primary pathogens predisposing deciduous trees for Armillaria attack [120]. In other biotic interactions of note, Riffle [121] and Cayrol et al. [122] found that nematodes (Aphelenchus avenae Bastian, A. cibolensis Riffle, and A. composticola Franklin) can actively destroy the mycelium of Armillaria. The qualitative and quantitative composition of compounds secreted by the roots often determines the development of the antagonistic microorganisms in the soil [123]. For example, A. mellea can be inhibited by gastrodianin 
(an anti-fungal protein from the parasitic plant Gastrodia which is affected by Trichoderma viride present in the soil $[124,125])$.

In areas transitioning from coniferous to deciduous trees, seasonal changes in oxygen and $\mathrm{CO}_{2}$ production due to photosynthesis and respiration are inevitable. Therefore, the additional supply of $\mathrm{CO}_{2}$. As the result of the decomposition of wood by pathogens and saprotrophs can tip the local and global carbon balance [19].

\section{The Microbial Soil Community}

Soil microbial communities are responsible for mineralization, decomposition, and nutrient cycling. These communities could be affected by abiotic factors in the climate such as temperature, moisture, and soil nutrient availability, or by biotic factors, particularly interactions with other microorganisms [126]. Certain interactions between antagonists and pathogens are initiated when the antagonistic fungi are under stress, especially nutrient stress, which has a direct impact on the growth, morphogenesis, and organogenesis of the antagonists [127]. The antagonistic fungi can receive nitrogen in the form of ammonium at high doses and they metabolize this form of nitrogen more intensively than do the pathogens. However, the pathogens have a relative advantage over antagonists when ammonium has been used up or the available nitrogen is in another form [127]. It is also known that many of the fungal isolates increase the formation of spores and chlamydospores when the concentration of nitrogen increases [128]. Armillaria species probably create rhizomorphs in similar situations.

Many authors report that global warming directly affects the metabolism and respiration of soil communities and the ratio of Gram-positive vs. Gram-negative bacteria [129], because these are sensitive to temperature [17,130-133] both in short-term and long-term scales [134]. The changes in temperature combined with the concomitant changes in soil moisture potentially affect many groups of fungal and bacterial communities [135]. Soil fungal communities shift from one dominant member to another while less-plastic bacterial communities remain more constant [136,137].

Greater or less active protection of plants against pathogens in the soil can result from the lack of ectomycorrhizal fungi as a result of climate changes (mainly drought) $[138,139]$. The insufficiency of mycorrhizas may stop or slow the adaptation of trees to new sites [140] and affect the ecosystem functioning [137], which could increase the susceptibility of trees to pathogens because trees are stressed. Symbiotic bacteria belonging to the Rhizobium genus [141] and mycorrhizal fungi [142] affect plant productivity by providing nutrients to plants. Mycorrhizal fungi can influence free-living bacterial communities to increase the transfer of nitrogen via mycorrhiza to the host plant [143]. However, interactions between mycorrhizal fungi and the host plant are not always mutualistic and can change due to environmental factors or even under plant stress [144]. Rising temperatures will lead to an increase in the allocation of carbon to mycorrhizal hyphae, which, depending on external conditions, can act as symbionts or parasites [145-148].

\section{The Interactions with Insect Pests}

Pfeffer [149] noted that after 1947, which was a "dry year," over $90 \%$ of trees colonized by bark beetle were attacked by Armillaria spp. Madziara-Borusiewicz and Strzelecka [150] reported from the Carpathian region that bark beetle first attack trees previously infected by Armillaria. James and Goheen [151] found that over $99 \%$ of dead or dying trees were affected by root diseases and $80 \%$ of them were simultaneously colonized by secondary pests. Capecki [152] has confirmed that stands attacked by Armillaria spp. are most strongly threatened by bark beetle in forests of the western Carpathians and that the occurrence of secondary pests is the natural result of greater susceptibility to disease and the poor sanitary state of the stands. In contrast, Christiansen and Husek [153] did not find any significant difference in rot occurrence between dead trees previously attacked by bark beetles and those not attacked by insects. Similarly, Jankovsky et al. [154] found a lack of relationship 
between the presence of the bark beetle Ips typographu and Armillaria spp. infection in spruce stands of the Szumawa Mountains (Czech Republic).

Twery et al. [155] reported the distribution of rhizomorphs of Armillaria spp. in uninjured mixed oak stands and in stands which were defoliated 1 and 5 years earlier by insects. Trees weakened by biotic stress were infested by Armillaria, with an increased abundance of rhizomorphs observed, especially on plots defoliated 5 years before sampling. The authors consider that trees' predisposal to pest invasions was a result of previous attack by Armillaria and deep water stress in the whole root system.

Okland et al. [156] supposed that a warmer climate would influence bark beetle populations, which may move north. The north European spruce forest, so far free from bark beetle outbreaks, showed strongly increased susceptibility to Ips spp. in climate change models [157-159]. Similarly, Langvall [160] connected the impact of global warming to the conditions of regeneration of Norway spruce towards the northern and higher elevations in Europe, and significant regional differences in the I. typographus behavior, such as voltinism. The negative impacts of drought and I. typographus populations in the southern range of the Norway spruce have been described by many authors [161-163]. Infection of spruce roots by Armillaria spp can cause production and release of specific compounds, for example, limonene, $\beta$-phellandrene, camphene, and bornyl acetate by needles and probably the phloem of weakened trees which are secondary pest attractants [164]. These signals can be specific to infection by Armillaria, and can encourage Ips spp. beetles to respond to these signals by choosing such trees for settlement [165].

\section{Conclusions}

Armillaria's life cycle, host susceptibility, and interactions with the soil and climate have been summarized in many papers. However, several gaps in research have been identified and further work could help us to predict climate change impacts on the pathogen and the forests. We hypothesize that climatic changes and global warming are not the only factors predisposing the roots of weakened trees to Armillaria infections, but that the bacteria and fungi, as well as macro-, meso-, and micro-organisms growing in the soil environment around root systems can also directly or indirectly enhance the proliferation of the pathogen and decrease the immune barriers in roots. The rhizomorphs are probably also colonized by endogenous bacteria and fungi that stimulate the growth of Armillaria hyphae and aid in the destruction of cell walls by the secretion of enzymes. This speculation requires further research.

Acknowledgments: Part of the study was financially supported by the Life Plus project HESOFF, Life 11 ENV / PL/459 financed by the European Union and the National Fund for Environmental Protection and Water Management in Warsaw.

Author Contributions: Katarzyna Kubiak and Zbigniew Sierota designed and conducted the text; all authors contributed to the manuscript preparation according to the professional experience.

Conflicts of Interest: There is no conflict of interest.

\section{References}

1. Keeling, C.D.; Whorf, T.P.; Wahlen, M.; van der Plicht, J. Inter annual extremes in the rate of rise of atmospheric carbon dioxide since 1980. Nature 1995, 375, 666-670. [CrossRef]

2. Intergovernmental Panel on Climate Change (IPCC). IPPC Fourth Assessment Report in Summary for Policymakers; IPCC: Geneva, Switzerland, 2007.

3. Bazzaz, F.A. The response of natural ecosystems to the rising global $\mathrm{CO}_{2}$ levels. Ann. Rev. Ecol. Syst. 1990, 21, 167-196. [CrossRef]

4. Climate Change 2001. Synthesis Report. A Contribution of Working Groups I, II, and III to the Third Assessment Report of the Integovernmental Panel on Climate Change; Watson, R.T., Core Writing Team, Eds.; Cambridge University Press: Cambridge, UK; New York, NY, USA, 2001.

5. Long, S.P.; Ainsworth, E.A.; Leakey, A.D.B.; Nösberger, J.; Ort, D.R. Food for thought: Lower-Than expected crop yield stimulation with rising $\mathrm{CO}_{2}$ concentrations. Science 2006, 312, 1918-1921. [CrossRef] [PubMed] 
6. Pearson, R.G.; Dawson, T.P. Predicting the impacts of climate change on the distribution of species: Are bioclimate envelope models useful? Glob. Ecol. Biogeogr. 2003, 12, 361-371. [CrossRef]

7. Brzeziecki, B.; Kienast, F.; Wildi, O. Modeling potential impact of climate change on the spatial distribution of zonal forest communities in Switzerland. J. Veg. Sci. 1995, 6, 257-268. [CrossRef]

8. Wargo, P.M.; Parker, J.; Houston, D.R. Starch content in roots of defoliated sugar maple. For. Sci. 1972, 18, 203-204.

9. Jung, T. Beech decline in Central Europe driven by the interaction between Phytophthora infections and climatic extremes. For. Pathol. 2009, 39, 77-94.

10. Trocha, L.K.; Weiser, E.; Robakowski, P. Interactive effects of juvenile defoliation, light conditions, and interspecific competition on growth and ectomycorrhizal colonization of Fagus sylvatica and Pinus sylvestris seedlings. Mycorrhiza 2016, 26, 47-56. [CrossRef] [PubMed]

11. Bonan, G.B. Forests and climate change: Forcings, feedbacks, and the climate benefits of forests. Science 2008, 320, 1444-1449. [CrossRef] [PubMed]

12. Santini, A.; Ghelardini, L.; De Pace, C.; Desprez-Loustau, M.L.; Capretti, P.; Chandelier, A.; Cech, T.; Chira, D.; Diamandis, S.; Gaitniekis, T.; et al. Biogeographical patterns and determinants of invasion by forest pathogens in Europe. New Phytol. 2013, 197, 238-250. [CrossRef] [PubMed]

13. Williams, W.M.A. Response of microbial communities to water stress in irrigated and drought-prone tallgrass prairie soils. Soil Biol. Biochem. 2007, 39, 2750-2757. [CrossRef]

14. Blankinship, J.C.; Niklaus, P.A.; Hungate, B.A. A meta-analysis of responses of soil biota to global change. Oecologia 2011, 165, 553-565. [CrossRef] [PubMed]

15. De Angelis, K.M.; Pold, G.; Topcuoglu, B.D.; van Diepen, L.T.A.; Varney, R.M.; Blanchard, J.L.; Melillo, J.; Frey, S.D. Long-Term forest soil warming alters microbial communities in temperate forest soils. Front. Microbiol. 2015, 6, 104.

16. Pettersson, M.; Baath, E. Temperature-Dependent changes in the soil bacterial community in limed and unlimed soil. FEMS Microbiol. Ecol. 2003, 45, 13-21. [CrossRef]

17. Bradford, M.A.; Davies, C.A.; Frey, S.D.; Maddox, T.R.; Melillo, J.M.; Mohan, J.E.; Reynolds, J.F.; Treseder, K.K.; Wallenstein, M.D. Thermal adaptation of soil microbial respiration to elevated temperature. Ecol. Lett. 2008, 11, 1316-1327. [CrossRef] [PubMed]

18. Hagerty, S.B.; van Groenigen, K.J.; Allison, S.D.; Hungate, B.A.; Schwartz, E.; Koch, G.W.; Kolka, R.K.; Dijkstra, P. Accelerated microbial turnover but constant growth efficiency with warming in soil. Nat. Clim. Chang. 2014, 4, 903-906. [CrossRef]

19. Sierota, Z. Wpływ grzybów rozkładających korzenie drzew leśnych na uwalnianie $\mathrm{CO}_{2}$ - próba waloryzacji [Effect of fungi decomposing roots of forest trees on $\mathrm{CO}_{2}$ release-An attempt of evaluation]. Sylwan 2012, 156, 128-136. (In Polish)

20. Lindner, M.; Garcia-Gonzalo, J.; Kolström, M.; Green, T.; Reguera, R. Impacts of Climate Change on European Forests and Options for Adaptation No. AGRI-2007-G4-06; Report to the European Commission Directorate-General for Agriculture and Rural Development: Brussels, Belgium.

21. La Porta, N.; Capretti, P.; Thomsen, I.M.; Kasanen, R.; Hietala, A.M.; Von Weissenberg, K. Forest pathogens with higher damage potential due to climate change in Europe. Can. J. Plant Pathol. 2008, 30, 177-195. [CrossRef]

22. Tubby, K.V.; Webber, J.F. Pests and diseases threatening urban trees under a changing climate. Forestry 2010, 83, 451-459. [CrossRef]

23. Szynkiewicz, A.; Kwasna, H. The susceptibility of forest trees to Armillaria root rot. Sylwan 2008, 148, 25-33. (In Polish)

24. Brockerhoff, E.G.; Jactel, H.; Goldarazena, A.; Berndt, L.; Bain, J. Risk assessment of European pests of Pinus radiata; Client Report No. 12216; ENSIS: Rotorua, New Zealand, 2006.

25. Rishbeth, J. Effects of soil temperature and atmosphere on growth of Armillaria rhizomorphs. Trans. Brit. Mycol. Soc. 1978, 70, 213-220. [CrossRef]

26. Keca, N. Characteristics of Armillaria species development and their growth at different temperatures. Bull. Fac. Forstry 2005, 91, 149-162. (In Serbian) [CrossRef]

27. Rind, B.; Losel, D.M. Effect of nutrients and temperature on the growth of Armillaria mellea and other fungi. Indus J. Biol. Sci. 2005, 2, 326-331. 
28. Guillaumin, J.J.; Legrand, P. Armillaria root rot. In Infectious Forest Diseases; Gonthier, P., Nicolotti, G., Eds.; CABI: Oxfordshire, UK, 2005; Chapter 8; pp. 159-177.

29. Pastor, J.; Post, W.M. Influence of Climate, Soil Moisture, and Succession on Forest Carbon and Nitrogen Cycles. Biogeochemistry 1986, 2, 3-27. [CrossRef]

30. Schwarze, F.W.M.R.; Engels, J.; Mattheck, C. Fungal Strategies of Wood Decay in Trees; Springer-Verlag: Berlin/Heidelberg, Germany, 2000.

31. Witomski, P. Zmiany Wybranych właściwości fizycznych i Chemicznych Drewna Sosny Zwyczajnej (Pinus sylvestris L.) pod Wptywem Rozkładu Białego i Brunatnego; SGGW: Warsaw, Poland, 2008. (In Polish)

32. Rayner, A.D.M.; Boddy, L. Fungal Decomposition of Wood. Its Biology and Ecology; J. Wiley \& Sons Ltd.: Chichester, Sussex, UK, 1988.

33. Sierota, Z. Dry weight loss of wood after the inoculation of Scots pine stumps with Phlebiopsis gigamtea. Eur. J. For. Path. 1997, 27, 179-185. [CrossRef]

34. Hintikka, V. Notes on the ecology of Armillaria mellea in Finland. Karstenia 1974, 14, 12-31.

35. Redfern, D.B. Infection of Picea sitchensis and Pinus contorta stumps by basidiospores of Heterobasidion annosum. Forest Pathol. 1982, 12, 11-25. [CrossRef]

36. Lech, P.; Żółciak, A. Wzrost sadzonek sosny zwyczajnej i rozwój ryzomorf opienki ciemnej w warunkach podwyższonej koncentracji $\mathrm{CO}_{2} \mathrm{w}$ powietrzu. (Growth of Scots pine seedlings and Armillaria ostoyae rhizomorphs under elevated air $\mathrm{CO}_{2}$, concentration conditions). Leś. Pr. Bad. 2006, 4, 17-34. (In Polish)

37. Wells, J.M.; Boddy, L. Effect of temperature on wood decay and translocation of soil-derived phosphorus in mycelial cord systems. New Phytol. 1995, 129, 289-297. [CrossRef]

38. Austin, E. Wood Decomposition in a Warmer World. Ph.D. Thesis, University of Tennessee, Knoxville, TN, USA, 2013.

39. Dang, C.K.; Schindler, M.; Chauvet, E.; Gessner, M.O. Temperature oscillation coupled with fungal community shifts can modulate warming effects on litter decomposition. Ecology 2009, 90, 122-131. [CrossRef] [PubMed]

40. Klopfenstein, N.B.; Kim, M.; Hanna, J.; Richardson, B.A.; Smith, A.L.; Maffei, H. Predicting potential impacts of climate change on Armillaria root disease in the inland northwestern USA. Phythopathology 2009, 99, S65.

41. Kliejunas, J.T.; Geils, B.; Glaeser, J.M.; Goheen, E.M.; Hennon, P.; Kim, M.-S.; Kope, H.; Stone, J.; Sturrock, R.; Frankel, S. Climate and Forest Diseases of Western North America: A Literature Review; U.S. Department of Agriculture, Forest Service, Pacific Southwest Research Station: Albany, CA, USA, 2008; p. 36.

42. Ramsfield, T.D.; Bentz, B.J.; Faccoli, M.; Jactel, H.; Brockerhoff, E.G. Forest health in a changing world: Effects of globalization and climate change on forest insect and pathogen impacts. Forestry 2016, 89, 245-252. [CrossRef]

43. Worrall, J. Armillaria root disease. In The Plant Health Instructor; The American Phytopathological Society (APS): St. Paul, MN, USA, 2004. [CrossRef]

44. Battles, J.J.; Robards, T.; Das, A.; Waring, K.; Gilless, J.K.; Biging, G.; Schurr, F. Climate change impacts on forest growth and tree mortality: A data-driven modeling study in a mixed-conifer forest of the Sierra Nevada. Clim. Chang. 2008, 87, S193-S213. [CrossRef]

45. Ayres, M.P.; Lombardero, M.J. Assessing the consequences of global change for forest disturbance from herbivores and pathogens. Sci. Total Environ. 2000, 262, 263-286. [CrossRef]

46. Lau, J.A.; Lennon, J.T. Evolutionary ecology of plant-microbe interactions: Soil microbial structure alters selection on plant traits. New Phytol. 2011, 192, 215-224. [CrossRef] [PubMed]

47. Horst, C.P.; Zee, P.C. Eco-Evolutionary dynamics in plant-soil feedbacks. Funct. Ecol. 2016, 30, 1062-1072.

48. Hood, I.A.; Redfern, D.B.; Kile, G.A. Armillaria in planted host. In Armillaria Root Diseases; Agricultural Handbook No. 691; Show, C.G., III, Kile, G.A., Eds.; U.S.D.A. Forest Service: Washington, DC, USA, 1991; pp. 122-149.

49. Worrall, J.J.; Sullivan, K.F.; Harrington, T.C.; Steimel, J.P. Incidence, host relations and population structure of Armillaria ostoyae in Colorado campgrounds. For. Ecol. Manag. 2004, 192, 191-206. [CrossRef]

50. Narayanasamy, P. Detection of Fungal Pathogens in Plants. In Microbial Plant Pathogens-Detection and Disease Diagnosis: Fungal Pathogens; Springer Science+Business Media: Dordrecht, The Netherlands, 2011; Volume 1.

51. McDonald, G.I.; Martin, N.E.; Harvey, A.E. Armillaria in the Northern Rockies: Pathogenicity and Host Susceptibility on Pristine and Disturbed Areas; USDA, FS Intermountain Research Station: Ogden, UT, USA, 1987. 
52. Van der Putten, W.H.; Klironomos, J.N.; Wardle, D.A. Microbial ecology of biological invasions. ISME J. 2007, 1, 28-37. [CrossRef] [PubMed]

53. Manabe, S.; Spelman, M.J.; Stouffer, R.J. Transient responses of a coupled ocean atmosphere model to gradual changes of atmospheric $\mathrm{CO}_{2}$. Part II: Seasonal response. J. Clim. 1992, 5, 105-126. [CrossRef]

54. Loretto, F.; Burdsall, H.; Tirro, A. Armillaria infection and water stress influence gas-exchange properties of mediterranean trees. Hort Sci. 1993, 28, 222-224.

55. Hadfield, J.S.; Goheen, D.J.; Filip, G.M.; Schmitt, C.L.; Harvey, R.D. Root Diseases in Oregon and Washington Conifers - R6-FPM-250-86; U.S.D.A. Forest Service: Portland, OR, USA, 1986.

56. Mullen, J.; Hagan, A. Alabama Cooperative Extension System. Available online: http://www.aces.edu/ pubs/docs / A/ANR-0907/ANR-0907.pdf (accessed 15 October 2004).

57. Szewczyk, W.; Kwaśna, H.; Behnke-Borowczyk, J. Armillaria population in flood-plain forest of natural pedunculate oak showing oak decline. Pol. J. Environ. Stud. 2016, 25, 1253-1262. [CrossRef]

58. Żółciak, A.; Lech, P.; Małecka, M.; Sierota, Z. Opieńkowa zgnilizna korzeni a stan zdrowotny drzewostanów świerkowych w Beskidach. PAU 2009, 11, 61-72. (In Polish)

59. Lamoure, D.; Guillaumin, J.J. The life cycle of the Armillaria mellea complex. Euro. J. For. Pathol. 1985, 15, 288-293. [CrossRef]

60. Maynard, D.G.; Paré, D.; Thiffault, E.; Lafleur, B.; Hogg, K.E.; Kishchuk, B. How do natural disturbances and human activities affect soils and tree nutrition and growth in the Canadian boreal forest? Environ. Rev. 2014, 22, 161-178. [CrossRef]

61. Żółciak, A. Występowanie grzybów z rodzaju Armillaria (Fr.: Fr.) Staude w kompleksach leśnych w Polsce (The occurence of Armillaria (Fr.: Fr.) Staude in forests stands in Poland). Pr. Inst. Bad. Leśn. Ser. A 1999, 888, 21-40. (In Polish)

62. Gregory, S.C.; Rishbeth, J.; Shaw, C.G., III. Pathogenicity and Virulence. In Armillaria Root Disease; Agricultural Handbook No. 691; Show, C.G., III, Kile, G.A., Eds.; U.S.D.A. Forest Service: Washington, DC, USA, 1991; pp. 76-87.

63. Guillaumin, J.J.; Mohammed, C.; Anselmi, N.; Courtecuisse, R.; Gregory, S.C.; Holdenrieder, O.; Intini, M.; Lung, B.; Marxmüller, H.; Morrison, D.; et al. Geographical distribution and ecology of the Armillaria species in western Europe. Eur. J. For. Path. 1993, 23, 321-341. [CrossRef]

64. Fox, R.T.V. Pathogenicity. In Armillaria Root Rot: Biology, and Control of Honey Fungus Section 3: Pathology; Fox, R.T.V., Ed.; Intercept Ltd.: Andover, UK, 2000; pp. 113-136.

65. Cleary, M.; van der Kamp, B.J.; Morrison, D.J. Pathogenicity and virulence of Armillaria sinapina and host response to infection in Douglas-fir, western hemlock and western redcedar in the southern interior of British Columbia. For. Patolh. 2012, 42, 481-491.

66. Ross-Davis, A.L.; Stewart, J.E.; Hanna, J.W.; Kim, M.S.; Knaus, B.J.; Cronn, R.; Rai, H.; Richardson, B.A.; McDonald, G.I.; Klopfenstein, N.B. Transcriptome of an Armillaria root disease pathogen reveals candidate genes involved in host substrate utilization at the host-pathogen interface. For. Patolh. 2013, 43, 468-477. [CrossRef]

67. Sicoli, G.; Annese, V.; de Gioia, T.; Luisi, N. Armillaria pathogenicity tests on oaks in southern Italy. J. Plant Path. 2002, 84, 107-111.

68. Lygis, V.; Vasiliauskas, R.; Larsson, K.; Stenlid, J. Wood-Inhabiting fungi in stems of Fraxinus excelsior in declining ash stands of northern Lithuania, with particular reference to Armillaria cepistipes. Scand. J. For. Res. 2005, 20, 337-346. [CrossRef]

69. Moricca, S.; Ginetti, B.T.B.; Scanu, B.; Franceschini, A.; Ragazzi, A. Endemic and emerging pathogens threatening cork oak trees: Management options for conserving a unique forest ecosystem. Plant Dis. 2016, 100, 2184-2193. [CrossRef]

70. Żółciak, A.; Bouteville, R.-J.; Tourvieille, J.; Roeckel-Drevet, P.; Nicolas, P.; Guillaumin, J.-J. Occurrence of Armillaria ectypa (Fr.) Lamoure in peat bogs of the Auvergne-the reproduction system of the species. Cryptogam. Mycol. 1997, 18, 299-313.

71. Brazee, N.J.; Ortiz-Santana, B.; Banik, M.T.; Lindner, D.L. Armillaria altimontana, a new species from the western interior of North America. Mycologia 2012, 104, 1200-1205. [CrossRef] [PubMed]

72. Pegler, D.N. Taxonomy, Nomenclature and Description of Armillaria. In Armillaria Root Rot: Biology and Control of Honey Fungus, Section 2: Diversity; Fox, R.T.V., Ed.; Intercept Ltd.: Andover, UK, 2000; pp. 81-93. 
73. Kim, M.-S.; Klopfenstein, N.B.; Hanna, J.W.; McDonald, G.I. Characterization of North American Armillaria species: Genetic relationships determined by ribosomal DNA sequences and AFLP markers. For. Pathol. 2006, 36, 145-164. [CrossRef]

74. Garett, S.D. Rhizomorph behavior in Armillaria mellea (Fr.) Quel., III Saprophytic colonization of woody substrates in soil. Ann. Bot. 1960, 24, 275-285.

75. Morrison, D.J. Rhizomorph growth, habit, saprophytic ability and virulence of 15 Armillaria species. For. Pathol. 2004, 34, 15-26. [CrossRef]

76. Leach, R. Biological control and ecology of Armillaria mellea (Vahl) Fr. T. Brit. Mycol. Soc. 1939, 23, $320-329$. [CrossRef]

77. Raabe, R.D.; Trujillo, E.E. Armillaria mellea in Hawaii. Plant Dis. Rep. 1963, 47, 776.

78. Redfern, D.B.; Filip, G.M. Inoculum and Infection. In Armillaria Root Disease; Agricultural Handbook No. 691; Show, C.G., III, Kile, G.A., Eds.; U.S.D.A. Forest Service: Washington, DC, USA, 1991; pp. 48-61.

79. Kile, G.A. Behaviour of Armillaria in some Eucalyptus obliqua - Eucalyptus regnans forests in Tasmania and its role in their decline. Eur. J. For. Pathol. 1980, 10, 278-296. [CrossRef]

80. Morrison, D.J. Studies on the Biology of Armillaria mellea. Ph.D. Thesis, University of Cambridge, Cambridge, UK, 1972.

81. Redfern, D.B. Growth and behaviour of Armillaria mellea rhizomorphs in soil. Trans. Br. Mycol. Soc. 1973, 61, 569-581. [CrossRef]

82. Rykowski, K. Niektóre troficzne uwarunkowania patogeniczności Armillaria mellea (Vahl) Quèl. w uprawach sosnowych. Prace Inst. Bad. Leśn. 1985, 640, 1-140. (In Polish)

83. Morrison, D.J. Vertical distribution of Armillaria mellea rhizomorphs in soil. Trans. Brit. Mycol. Soc. 1976, 66, 393-399. [CrossRef]

84. Morrison, D.J.; Thomson, A.J.; Chu, D.; Peet, F.G.; Sahota, T.S. Variation in isozyme patterns of esterase and polyphenol oxidase among isolates of Armillaria ostoyae from British Columbia. Can. J. Plant Pathol. 1989, 11, 229-234. [CrossRef]

85. Mihail, J.D.; Bruhn, J.N. Foraging behaviour of Armillaria rhizomorph systems. Mycol. Res. 1995, 109, 1195-1207. [CrossRef]

86. Mihail, J.D.; Obert, M.; Bruhn, J.N. Fractal geometry of diffuse mycelia and rhizomorphs of Armillaria species. Mycol. Res. 1995, 99, 81-88. [CrossRef]

87. Żółciak, A.; Sierota, Z. Zabiegi hodowlane a zagrożenie drzewostanów przez patogeny korzeni. Prace Inst. Bad. Leśn. seria B 1997, 31, 71-84. (In Polish)

88. Żółciak, A. Przydatność herbicydu Roundup do ograniczania rozwoju ryzomorf opieniek w uprawach leśnych.). Prace Inst. Bad. Leśn. Seria A 2001, 910, 65-83. (In Polish)

89. Żółciak, A. Refraining the regeneration of Armillaria rhizomorphs using Trichoderma. Bulletin of the Polish Academy of Sciences. Biol. Sci. 2001, 49, 265-273.

90. Baumgartner, K.; Coetzee, M.P.A.; Hoffmeister, D. Secrets of the subterranean pathosystem of Armillaria. Mol. Plant Path. 2011, 12, 515-534. [CrossRef] [PubMed]

91. Morrison, D.J. Effects of soil organic matter on rhizomorph growth by A. mellea. Trans. Brit. Mycol. Soc. 1982, 78, 201-207. [CrossRef]

92. Singh, P. Armillaria root rot: Influence of soil nutrients and $\mathrm{pH}$ on the susceptibility of conifer species to the disease. Eur. J. For. Pathol. 1983, 13, 92-101. [CrossRef]

93. Mihail, J.D.; Bruhn, J.N.; Leininger, T.D. The effects of moisture and oxygen availability on rhizomorphs generation by Armillaria tabescens in comparison with A. gallica and A. mellea. Mycol. Res. 2002, 106, 697-704. [CrossRef]

94. Kessler, W.; Moser, S. Moglichkeiten der Vorbeugung gegen Schaden durch Hallimasch in Kiefernkulturen. Beitr. fur die Forstwirtsch. 1974, 8, 86-89.

95. Rishbeth, J. The growth rate of Armillaria mellea. Trans. Brit. Mycol. Soc. 1986, 51, 575-586. [CrossRef]

96. Pearce, M.H.; Malajczuk, N. Factors affecting the growth of Armillaria luteobubalina rhizomorphs in soil. Mycol. Res. 1990, 94, 38-48. [CrossRef]

97. Blenis, P.V.; Mugala, M.S.; Hiratsuka, Y. Soil affects Armillaria root rot of lodgepole pine. Can. J. For. Res. 1989, 19, 1638-1641. [CrossRef]

98. Singh, P. Armillaria root rot: Influence of soil nutrients and $\mathrm{pH}$ on the susceptibility of conifer species to the disease. For. Pathol. 2007, 13, 92-101. [CrossRef] 
99. Prescott, L.M.; Harley, J.P.; Klein, D.A. Human Diseases Caused by Bacteria, Part X Microbial Diseases and Their Control. In Microbiology, 5th ed.; the McGraw-Hill Companies: Columbus, OH, USA, 2002; pp. 900-940.

100. Mallett, K.I.; Meynard, D.G. Armillaria root disease, stand characteristics, and soil properties in young lodgepole pine. For. Ecol. Manag. 1998, 105, 37-44. [CrossRef]

101. Lech, P.; Żółciak, A. Uwarunkowania występowania opieńkowej zgnilizny korzeni w lasach Beskidu Żywieckiego. Leś. Pr. Bad. 2006, 2, 33-49. (In Polish).

102. Schinner, F.; Concin, R. Carbon dioxide fixation by wood rotting fungi. Eur. J. For. Pathol. 1981, 11, $120-123$. [CrossRef]

103. Herms, D.A.; Mattson, W.J. The dilemma of plants: to grow or defend. Q. Rev. Biol. 1992, 67, $283-335$. [CrossRef]

104. Drigo, B.; Kowalchuk, C.A.; van Veen, J.A. Climate change goes underground: Effects of elevated atmospheric $\mathrm{CO}_{2}$ on microbal community structure and activities in the rhizosphere. Biol. Fert. Soils 2008, 44, 667-679. [CrossRef]

105. Sallas, L.; Kainulainen, P.; Utrainen, J.; Holopainen, T.; Holopainen, J.K. The influence of elevated $\mathrm{O}_{3}$ and $\mathrm{CO}_{2}$ concentrations on secondary metabolites of Scots pine (Pinus sylvestris L.) seedlings. Glob. Chang. Biol. 2001, 7, 303-311. [CrossRef]

106. Fleischmann, F.; Raidl, W.F.; Oßwald, W.F. Changes in susceptibility of beech (Fagus sylvatica) seedlings towards Phytophthora citricola under the influence of elevated atmospheric $\mathrm{CO}_{2}$ and nitrogen fertilization. Environ. Pollut. 2010, 158, 1051-1060. [CrossRef] [PubMed]

107. Tkaczyk, M.; Sikora, K.; Nowakowska, J.A.; Kubiak, K.; Oszako, T. Effects of $\mathrm{CO}_{2}$ enhancement on beech (Fagus sylvatica L.) seedling root rot due to Phytophthora plurivora and Phytophthora cactorum. Folia For. Pol. Ser. A 2014, 56, 149-156. [CrossRef]

108. Oszako, T.; Sikora, K.; Borys, M.; Kubiak, K.; Tkaczyk, M. Phytophthora quercina infections in elevated $\mathrm{CO}_{2}$ concentrations. Folia For. Pol. Ser. A 2016, 58, 131-141. [CrossRef]

109. Grzywacz, A.; Ważny, J. The impact of industrial air pollutants on the occurrence of several important pathogenic fungi of forest trees in Poland. Eur. J. For. Pathol. 1973, 3, 129-141. [CrossRef]

110. Jancarik, U. Uyskyt drevokaznych hub u Kourem poskozovane oblasti Krusnych hor. Lesnictvi 1962, 1, 677-692.

111. Kude1a, M.; Novakova, E. Lesni skudci a skody sveri v lesich poskozovanych Kourem. Lesnictvi 1962, 6, 493-502.

112. Schaeffer, T.C.; Hedgecock, G.G. Injury to Northwestern Forest Trees by Sulfur Dioxide from Smelters; U.S. Forest Service Tech. Bull. No. 1117; U.S.D.A.: Washington, DC, USA, 1955; pp. 1-49.

113. Domanski, S.; Kowalski, S.; Kowalski, T. Fungi; occurring in forests injured by industrial air pollutants in the upper Silesia and Krakow industrial regions Poland: IV Higher fungi causing root diseases within forest stands not rebuilt in the years 1971-1975. Acta Agrar. Silv. Ser. Silv. 1976, 16, 61-74.

114. Horak, M.; Tesche, M. Einfluss von $\mathrm{SO}_{2}$ auf die Infektione von Fichtensamlingen durch Armillaria ostoyae. Forstwiss. Cbl. 1993, 112, 93-97. [CrossRef]

115. Wargo, P.M.; Carey, A.C. Effects of metals and $\mathrm{pH}$ on in vitro growth of Armillaria ostoyae and other root and butt rot fungi of red spruce. For. Pathol. 2001, 41, 5-24. [CrossRef]

116. Sicoli, G.; Luisi, N.; Manicone, R.P. Armillaria species occurring in southern Italy. In Proceedings of the Eighth International Conference on Root and Butt Rots, Wik, Sweden and Haikko, Finland, 9-16 August 1993; Johansson, M., Stenlid, J., Eds.; Swedish University of Agriculture Sciences: Uppsala, Sweden, 1994; pp. 383-387.

117. Cruickshank, M.G.; Morrison, D.J.; Punja, Z.K. Incidence of Armillaria species in precommercial thinning stumps and spread of Armillaria ostoyae to adjacent Douglas-fir-trees. Can. J. For. Res. 1997, 27, 481-490. [CrossRef]

118. Lygis, V. Root Rot in North-Temperate Forest Stands: Biology, Management and Communities of Associated Fungi. Ph.D. Thesis, Swedish University of Agricultural Sciences, Forestry Faculty, Uppsala, Sweden, 2005.

119. Dumas, M.T.; Boyonoski, N.W. Scanning electron microscopy of mycoparasitism of Armillaria rhizomorphs by species Trichoderma. Eur. J. For. Pathol. 1992, 22, 379-383. [CrossRef]

120. De Wit, P.J.G.M. Plant Pathogenic Fungi and Oomycetes. In Principles of Plant-Microbe Interactions; Lugtenberg, B., Ed.; Springer Int. Publisher: Cham, Switzerland, 2015; pp. 79-90. 
121. Riffle, J.W. Effect of two mycophagus nematodes on Armillaria mellea root rot of Pinus ponderosa seedlings. Plant Dis. Rep. 1973, 57, 355-357.

122. Cayrol, J.C.; Dubos, B.; Guillaumin, J.-J. Etude preliminare in vitro de l'agressivite de quelque nematodes mycophages vis-à-vis de Trichoderma viride Pers., T. polysporum (Link. Ex Pers.) Rifai et Armillaria mellea (Vahl) Karst. Ann. Phytopathol. 1978, 10, 177-185.

123. Weller, D.M. Biological control of soilborne plant pathogens in the rhizosphere. Ann. Rev. Phytopathol. 1988, 26, 379-407. [CrossRef]

124. Sa, Q.; Wang, Y.; Li, W.; Zhang, L.; Sun, Y. The promoter of an antifungal protein gene from Gastrodia elata confers tissue-specific and fungus-inducible expression patterns and responds to both salicylic acid and jasmonic acid. Plant Cell Rep. 2003, 22, 79-84. [CrossRef] [PubMed]

125. Wang, H.X.; Yang, T.; Zeng, Y.; Hu, Z. Expression analysis of the gastrodianin gene ga4B in an achlorophyllous plant Gastrodia elata Bl. Plant Cell Rep. 2007, 26, 253-259. [CrossRef] [PubMed]

126. Singh, B.K.; Dawson, L.A.; Macdonald, C.A.; Buckland, S.M. Impact of biotic and abiotic interaction on soil microbial communities and functions: A field study. Appl. Soil Ecol. 2009, 41, 239-248. [CrossRef]

127. Celar, F. Competition for amonium and nitrate forms of nitrogen between some phytopathogenic and antagonistic soil fungi. Biol. Control 2003, 28, 19-24. [CrossRef]

128. Watanabe, N.; Lewis, J.A.; Papavizas, G.C. Influence of nitrogen fertilizers on growth, spore production and germination, and biological potential of Trichoderma and Gliocladium. J. Phtopathol. 1987, 120, 337-346. [CrossRef]

129. Zogg, G.P.; Zak, D.R.; Ringelberg, D.B.; Macdonald, N.W.; Pregitzer, K.S.; White, D.C. Compositional and functional shifts in microbial communities because of soil warming. Soil Sci. Soc. Am. J. 1997, 61, 475-481. [CrossRef]

130. Karhu, K.; Auffret, M.D.; Dungait, J.A.J.; Hopkins, D.W.; Prosser, J.I.; Singh, B.K.; Subke, J.A.; Wookey, P.A.; Ågren, G.I.; Sebastià, M.T.; et al. Temperature sensitivity of soil respiration rates enhanced by microbial community response. Nature 2014, 513, 81-84. [CrossRef] [PubMed]

131. Anderson, O.R. Soil respiration, climate change and the role of microbial communities. Protist 2011, 162, 679-690. [CrossRef] [PubMed]

132. Giardina, C.P.; Litton, C.M.; Crow, S.E.; Asner, G.P. Warming-Related increases in soil $\mathrm{CO}_{2}$ efflux are explained by increased below-ground carbon flux. Nat. Clim. Chang. 2014, 4, 822-827. [CrossRef]

133. Carey, J.C.; Tang, J.; Templer, P.H.; Kroeger, K.D.; Crowther, T.W.; Burton, A.J.; Dukes, J.S.; Emmett, B.; Frey, S.D.; Heskel, M.A.; et al. Temperature response of soil respiration largely unaltered with experimental warming. Proc. Natl. Acad. Sci. USA 2016, 113, 13797-13802. [CrossRef] [PubMed]

134. Frey, S.D.; Lee, J.; Melillo, J.M.; Six, J. The temperature response of soil microbial efficiency and its feedback to climate. Nat. Clim. Chang. 2013, 3, 395-398. [CrossRef]

135. Briones, M.J.I.; McNamara, N.P.; Poskitt, J.; Crow, S.E.; Ostle, N.J. Interactive biotic and abiotic regulators of soil carbon cycling: Evidence from controlled climate experiments on peatland and boreal soils. Glob. Chang. Biol. 2014, 20, 2971-2982. [CrossRef] [PubMed]

136. Kaisermann, A.; Maron, P.A.; Beaumelle, L.; Lata, J.C. Fungal communities are more sensitive indicators to non-extreme soil moisture variations than bacterial communities. Appl. Soil Ecol. 2015, 86, 158-164. [CrossRef]

137. Classen, A.T.; Sundqvist, M.; Henning, J.A.; Newman, G.S.; Moore, J.A.M.; Cregger, M.; Moorhead, L.C.; Patterson, C.M. ESA Centennial Paper: Direct and indirect effects of climate change on soil microbial and soil microbial-plant interactions: What lies ahead? Ecosphere 2015, 6, 130. [CrossRef]

138. Campbell, A.H.; Harder, T.; Nielsen, S.; Kjelleberg, S.; Steinberg, P.D. Climate change and disease: Bleaching of a chemically defended seaweed. Glob. Chang. Biol. 2011, 17, 2958-2970. [CrossRef]

139. Morriën, E.; Engelkes, T.; van der Putten, W.H. Additive effects of aboveground polyphagous herbivores and soil feedback in native and range-expanding exotic plants. Ecology 2011, 92, 1344-1352. [CrossRef] [PubMed]

140. Nuñez, M.A.; Horton, T.R.; Simberloff, D. Lack of belowground mutualisms hinders Pinaceae invasions. Ecology 2009, 90, 2352-2359. [CrossRef] [PubMed]

141. De Bello, F.; Lavorel, S.; Díaz, S.; Harrington, R.; Cornelissen, J.H.C.; Bardgett, R.D.; Berg, M.P.; Cipriotti, P.; Feld, C.K.; Hering, D.; et al. Towards an assessment of multiple ecosystem processes and services via functional traits. Biodivers. Conserv. 2010, 19, 2873-2893. [CrossRef] 
142. Yang, G.; Yang, X.; Zhang, W.; Wei, Y.; Ge, G.; Lu, W.; Sun, J.; Liu, N.; Kan, H.; Shen, Y.; et al. Arbuscular mycorrhizal fungi affect plant community structure under various nutrient conditions and stabilize the community productivity. OIKOS 2016, 125, 576-585. [CrossRef]

143. Van der Heijden, M.G.A.; de Bruin, S.; Luckerhoff, L.; van Logtestijn, R.S.P.; Schlaeppi, K. A widespread plant-fungal-bacterial symbiosis promotes plant biodiversity, plant nutrition and seedling recruitment. ISME J. 2016, 10, 389-399. [CrossRef] [PubMed]

144. Streitwolf-Engel, R.; van der Heijden, M.G.A.; Wiemken, A.; Sanders, I.R. The ecological significance of arbuscular mycorrhizal fungal effects on clonal reproduction in plants. Ecology 2001, 82, 2846-2859. [CrossRef]

145. Grimoldi, A.A.; Kavanová, M.; Lattanzi, F.A.; Schnyder, H. Phosphorus nutrition-mediated effects of arbuscular mycorrhiza on leaf morphology and carbon allocation in perennial ryegrass. New Phytol. 2005, 168, 435-444. [CrossRef] [PubMed]

146. Elmore, W.C. Population and Identification of Mycorrhizal Fungi in St. Augustinegrass in Florida and Their Effect on Soilborne Pathogens. Ph.D. Thesis, University of Florida, Gainesville, FL, USA, 2006.

147. Olsson, P.A.; Hansson, M.C.; Burleigh, S.H. Effect of P availability on temporal dynamics of carbon allocation and Glomus intraradices high-affinity $\mathrm{P}$ transporter gene induction in arbuscular mycorrhiza. Appl. Environ. Microbiol. 2006, 72, 4115-4120. [CrossRef] [PubMed]

148. Hawkes, C.V.; Hartley, I.P.; Ineson, P.; Fitter, A.H. Soil temperature affects carbon allocation within arbuscular mycorrhizal networks and carbon transport from plant to fungus. Glob. Chang. Biol. 2008, 14, 1181-1190. [CrossRef]

149. Pfeffer, A. Sucha 1947 a kurovci na smrku v r. 1949. CsL. Les. 1950, 30, 176-179. (In Czech)

150. Madziara-Borusiewicz, K.; Strzelecka, H. Conditions of spruce (Picea excelsa) infestations by the engraver beetle (Ips typographus L.) in mountains in Poland. I. Chemical composition of volatile oils from healthy trees and those infested with the honey fungus (Armillaria mellea (Vahl) Quel. J. Appl. Entomol. 1977, 83, 409-415.

151. James, R.L.; Goheen, D.J. Conifer mortality associated with root disease and insects in Colorado. Plant Dis. 1981, 65, 506-507. [CrossRef]

152. Capecki, Z. Rejony zdrowotności zachodniej części Karpat. Prace IBL 1994, 781, 61-125. (In Polish)

153. Christiansen, E.; Husek, K.J. Infestation ability of Ips typographus in Norway spruce, in relation to butt rot, tree vitality and increment. Medd. Nor. Inst. Skogforsk. 1980, 35, 468-482.

154. Jankovsky, L.; Cudlin, P.; Moravec, I. Root decays as a potential predisposition factor of a bark beetle disaster in the Sumava Mts. J. For. Sci. 2003, 49, 125-132.

155. Twery, M.J.; Mason, G.N.; Wargo, P.M.; Gottschalk, K.W. Abundance and distribution of rhizomorphs of Armillaria spp. in defoliated mixed oak stands in western Maryland. Can. J. For. Res. 1990, 20, 674-678. [CrossRef]

156. Okland, B.; Krokene, P.; Lange, H. Science Nordic. The Effect of Climate Change on the Spruce Bark Beetle. Available online: http:www.cicero.uio.no/fulltex/index (accessed on 21 April 2015).

157. Seidl, R.; Rammer, W.; Lexer, M.J. Schätzung von Bodenmerkmalen und Modellparametern für die Waldökosystemsimulation auf Basis einer Großrauminventur. Allg. Forst-Jagdztg 2009, 180, 35-44. (In German)

158. Seidl, R.; Fernandes, P.M.; Fonseca, T.F.; Gillet, F.; Jönsson, A.M.; Merganicova, K.; Netherer, S.; Arpaci, A.; Bontemps, J.D.; Bugmann, H.; et al. Modelling natural disturbances in forest ecosystems: A review. Ecol. Model. 2011, 222, 903-924. [CrossRef]

159. Seidl, R.; Rammer, W.; Lexer, M.J. Climate change vulnerability of sustainable forest management in the Eastern Alps. Clim. Chang. 2011, 106, 225-254. [CrossRef]

160. Langvall, O. Impact of climate change, seedling type and provenance on the risk of damage to Norway spruce (Picea abies (L.) Karst.) seedling in Sweden due to early summer frosts. Scand. J. For. Res. 2011, 26, 56-63. [CrossRef]

161. Faccoli, M. Effect of weather on Ips typographus (Coleoptera Curculionidae) phenology, voltinism, and associated spruce mortality in the southeastern. Alps. Environ. Entomol. 2009, 38, 307-316. [CrossRef] [PubMed]

162. Marini, L.; Ayres, M.P.; Battisti, A.; Faccoli, M. Climate affects severity and altitudinal distribution of outbreaks in an eruptive bark beetle. Clim. Chang. 2012, 115, 327-341. [CrossRef] 
163. Marini, L.; Liedelow, A.; Jönsson, A.M.; Wulff, S.; Schroeder, L.M. Population dynamics of the spruce bark beetle: A long term study. Oikos 2013, 112, 1768-1776. [CrossRef]

164. Pham, T.; Chen, H.; Yu, J.; Dai, L.; Zhang, R.; Vu, T.Q.T. The Differential Effects of the Blue-Stain Fungus Leptographium qinlingensis on Monoterpenes and Sesquiterpenes in the Stem of Chinese White Pine (Pinus armandi) Saplings. Forests 2014, 5, 2730-2749. [CrossRef]

165. Schiebe, C.; Hammerbacher, A.; Birgersson, G.; Witzell, J.; Brodelius, P.; Gershenzon, J.; Hansson, B.S.; Krokene, P.; Schyler, F. Inducibility of chemical defences in Norway spruce bark is correlated with unsuccessful mass attacks by the spruce bark beetle. Oecologia 2012, 170, 183-198. [CrossRef] [PubMed]

(c) (2)

(C) 2017 by the authors. Licensee MDPI, Basel, Switzerland. This article is an open access article distributed under the terms and conditions of the Creative Commons Attribution (CC BY) license (http:/ / creativecommons.org/licenses/by/4.0/). 